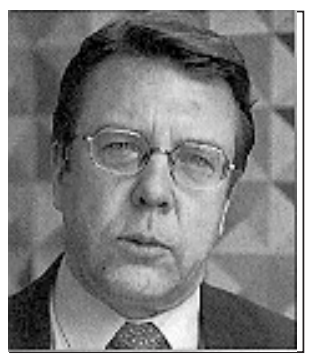

Seppo Tella

\title{
Tietokoneperustaisesta opetuksesta verkostopohjaiseen oppimiseen
}

\author{
Parinkymmenen viime vuoden aikana on tapahtunut valtava muutos \\ siirtymisessä tietokoneperustaisesta opetuksesta (computer-based \\ education) verkostopohjaiseen oppimiseen (network-based learn- \\ ing) samoin kuin opettamisen ja oppimisen painotuksissa. \\ Tässä artikkelissa tarkastellaan joitain kehitysvaiheita kuvaavia \\ siirtymiä ja pohditaan samalla niiden vaikutusta \\ opetus-oppimisprosessiin.
}

Artikkelin luonnehdinnat ovat alustavia, koska olemme liian lähellä muutosprosessia, jotta voisimme nähdä täsmälleen, mistä kaikesta on kysymys. Artikkelin tarkoituksena onkin toisaalta virittää keskustelua tieto- ja viestintätekniikan lähihistoriasta, jotta ymmärtäisimme paremmin oman tilamme.

\section{Tietokoneperustaisuus ja automaattinen tietojenkäsittely}

Tietokoneperustaisuus, tietokoneperustainen opetus (computer-based education, CBE) ja automaattinen tietojenkäsittely (automatic data processing, ADP) palautuvat 1960- ja 1970-lukujen käsitteistöön. Nykyinen telelogisesti määritelty, ts. tieto- ja viestintätekniikkaa sekä avointa ja etäopiskelua korostava mediakasvatus (media education) on saanut paljon vaikutteita näistä lähtökohdista, joskin esimerkiksi vaikutteet kognitiivisesta psykologiasta ja sosiokulttuurisesta tutkimuksesta ovat olleet omiaan monipuolistamaan tätä kehitystä.
Tietokoneperustaisesta tietokonejohtoiseen ja -avusteiseen opetukseen eli CBE ---> CMI ja CAI

CBE oli laaja yleiskäsite, jonka alle mahtuivat lähes kaikki opetukseen liittyvät sovellukset. Varsin pian, oikeastaan jo 1960-luvulla, mutta varsin selkeästi 1970-luvun loppupuolella mikrotietokoneiden alkaessa tulla opettajien tietoisuuteen, käsite jakautui kahteen: toisaalta tietokonejohtoiseen opetukseen (computer-managed instruction, CMI) ja toisaalta tietokoneavusteiseen opetukseen (computer-assisted instruction, $C A I)$. (Ks. kuvio 1.)

CMI sai pysyvän jalansijan erityisesti Yhdysvalloissa, jossa uskottiin vakaammin kuin Euroopassa siihen, että tietokone, siis tietokoneohjelma ja sen laatija, pystyisi hoitamaan koko opetusprosessin tavoitteiden asettelusta opetukseen ja arviointiin asti. CMI:n taustalla voitaneen nähdä jossain määrin perusteeton optimismi tietokonetekniikan kaikkipätevään voimaan, 
joka todella syrjäyttäisi vähitellen ainakin osan opettajista. Käsitteessä keskeistä on myös huomata instruction-sanan käyttö. Puuttumatta tässä yhteydessä tarkemmin poleemiseen rajankäyntiin teaching- ja instruction-käsitteiden välillä, voinee silti todeta, että instruction korostaa tavallisesti juuri käden- tai yleisemmin kehon motorisia taitoja ja teknisen suorittamisen opettamista ja siis käytännöllistä osaamista.

CAI puolestaan alkoi Yhdysvalloissa aikakautena, jolloin oppimiskäsitystä leimasi voimakas usko behaviorismiin ja ohjelmoituun opetukseen. Yleistäen voi ehkä väittää, että "drill and kill" tyyppinen perusasennoituminen on jatkunut yhdysvaltalaisessa tietokoneavusteisessa oppimateriaalissa aivan viime päiviin asti. Behavioristiseen oppimiskäsitykseen pohjaava CAI-tyyppinen ohjelmistotuotanto rakentuu tarkoin jäsenneltyjen opetuskokonaisuuksien varaan, joiden ohjelmointi on luonnollisesti helpompaa kuin esimerkiksi monivaihtoehtoisten, heurististen oppimistehtävien suunnittelu. Esitetystä kritiikistä huolimatta on helppo myös myöntää se valtava vaikutus, joka CAI:llä on ollut ja on edelleen opetuksen kehittymisessä.

Euroopassa kehitys eteni hieman toisin. CMI:n sijaan painottui aluksi CAI, sitten CAL (computer-assisted learning) eli tietokoneavusteinen oppiminen tai opiskelu. Kyse ei ole vain terminologisesta erosta vaan nimenomaan käsitteellisestä eli konseptuaalisesta muutoksesta, jossa teknisen opettamisen sijasta alettiin tähdentää oppimista. Reunahuomautuksena todettakoon, että näissä yhteyksissä englannin 'learning' tulisi oikeastaan kääntää opiskeluksi, mutta että tässä artikkelissa käytetään suomessa melko vakiintunutta käännöstä 'oppiminen'. Eri aineissa akronyymi CAL, suomeksi TAO, sai tarkentavia lisiä. Esimerkiksi tietokoneavusteista kieltenopetusta (TAKO) kutsuttiin englanniksi CALL (computer-assisted language learning). Suomessa säilyi termi 'opetus' monissa näistä lyhenteistä. Edelleen voisi todeta, että assisted-sanan sijaan käytettiin pitkään myös muotoa computer-aided, mutta AIDSin levitessä kansainvälinen kirjallisuus siirtyi suorastaan yksimielisesti suosimaan assisted-sanaa. Viime vuosina sen on korvannut monissa yhteyksissä enhanced (tehostettu, esim. computer-enhanced language learning, CELL). Yleistäen voi todeta, että tietokoneavusteiset opetusohjelmat ovat monipuolistuneet ja edustavat tällä hetkellä monia oppimisen suuntauksia.

\section{Tietotekniikan ja viestintätekniikan yhdentymisprosessi}

Automaattisen tietojenkäsittelyn (ATK, sittemmin atk) historia on pitkä, mutta tässä yhteydessä sitä tarkastellaan vain lähtökohtaterminä tietotekniikan kehittymiselle. Sinänsä kiintoisaa on todeta, että termi atk on säilynyt näihin päiviin jonkinlaisena yleisterminä, vaikka koulumaailmassa sillä on varsin rajallinen funktio ja olisi ollut jo pitkään loogisempaa puhua tietotekniikasta. Teknisen atk:n ja tietojenkäsittelyopin tai -tieteen (computer science) asemaa koulumaailmassa ei tarkastella tässä artikkelissa.

1980-luvun alkupuolella, erityisesti Suomessa, tietotekniikka (information technology, IT) merkitsi sekä tieteenaluetta että yhä yleisemmin yleissivistävän koululaitoksen oppiainetta. Oppiaineen kannalta tietokoneavusteinen opetus oli keskeisessä asemassa 1980-luvun alkupuolella. Kuitenkin noin 1985 (esim. Kivinen \& Konttinen 1985) työvälineohjelmien merkitys alkoi nousta yhä keskeisemmäksi. Ymmärrettiin, että lähes kertakäyttöisistä opetusohjelmista oli tarpeen siirtyä kestävämpien ja joka koulutustasolle sopivien työvälineohjelmien käyttöön. Keskeisiin työvälineohjelmiin luettiin tekstinkäsittely, tiedonhallinta, taulukkolaskenta, piirrosohjelmat, kuvan- ja äänenkäsittely jne. Ehkä on syytä myös huomauttaa, että monissa työvälineohjelmissa on loisteliaasti toteutettu opetusosa ("tutoriaali“), josta hyötyy sekä aloitteleva että kokenutkin käyttäjä. Viestintää korostavat ohjelmat eivät 1980 -luvun puolivälissä vielä olleet esillä kasvatuksessa tai opetuksessa, vaikka liike-elämä oli jo ottanut niitä käyttöön. 


\section{From computer-based education (CBE) toward network-based learning (NBL)}

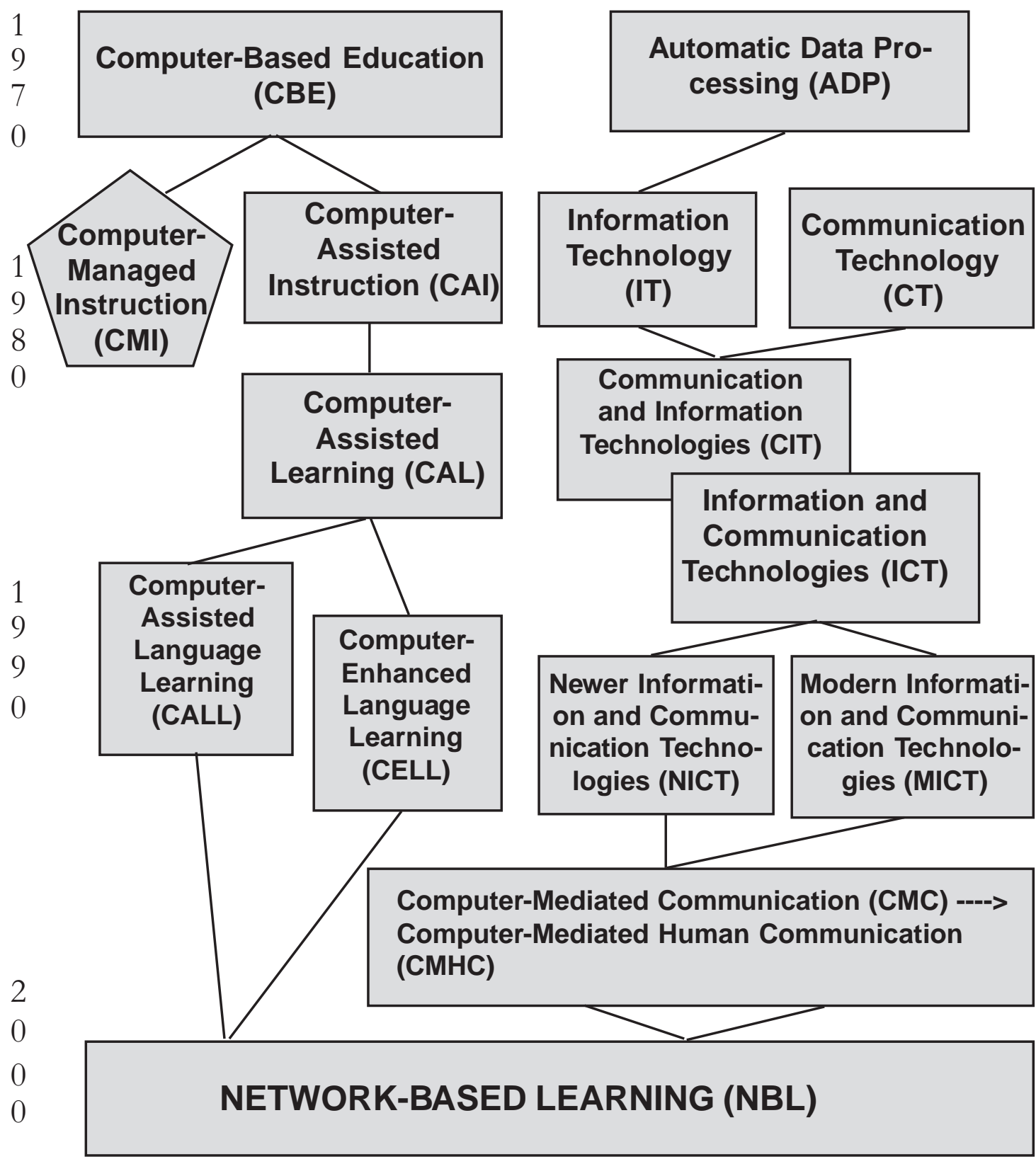

Kuvio 1.Erä itä sirtymäva iheita tietokonepenusteisesta opetuksesta (computer-based education,CBE) verkostopohja iseen oppimiseen (network-based leaming,NBL).(Tellan 1997,13pohja Ita edelleen muokattu.) 
Samanaikaisesti kehittyivät kuitenkin myös viestintätekniikat ja -ohjelmat (communication technology, CT). Näistä keskeisin ja tärkeimmäksi muotoutuva oli sähköposti, jota vielä 10 vuotta sitten kutsuttiin elektroniseksi postiksi. 1980-luvun loppupuolella IT ja CT alkoivat yhdentyä, joskin koulukäytössä tämä kehitys alkoi näkyä vasta 1990-luvulla (esim. Tella 1991; Tella 1992a; Tella 1992b). Kehitys oli alkuun varsin hidasta johtuen osittain myös laite- ja ohjelmistotekniikan puutteellisuudesta ja tietokoneiden muistikapasiteetin rajallisuudesta. Yhtenä esimerkkinä IT:n ja CT:n yhdentymisestä voidaan nähdä teksturin ja sähköpostiohjelmien integroituminen, joka on mahdollistanut myös muotoiltujen tiedostojen ja ohjelmien lähettämisen sähköpostiviestien liitetiedostoina.

Myös terminologiassa tapahtui muutoksia. Suomeksi alettiin puhua tieto- ja viestintätekniikasta, englanniksi ensin CIT:sta (communication and information technologies), joka pian muuttui ICT:ksi (information and communication technologies). CIT-akronyymiä käytettiin jonkin aikaa 1980-luvun lopussa ja 1990-luvun alussa monissa virallisissakin asiakirjoissa, mutta CIT-lyhenteen aiheuttama hymyreaktio englantia äidinkielenään puhuvissa aiheutti pian kirjainvaihdoksen.

On tärkeää huomata, että kyseessä ei ollut nytkään silkka terminologinen muutos vaan kyseessä oli siirtyminen uudentyyppiseen tietotyötekniseen ympäristöön. Myös koululaitoksen kannalta siirtymä oli onnekas ja tervetullut, koska samanaikaisesti viestinnän merkitys alkoi korostua useiden eri oppiaineiden opetuksessa. Esimerkiksi vieraissa kielissä oli tapahtumassa siirtymä kommunikatiiviseen ja kollaboratiiviseen opetukseen, jossa viestinnällä ja omakohtaisella kokemuksella, eksperientiaalisella oppimisella, tuli olemaan keskeinen rooli. Vuoden 1985 ja erityisesti vuoden 1994 valtakunnalliset opetussuunnitelman perusteet toimivat myös osaltaan viestinnän kenttää vapauttavana. Opetuksen ja oppimisen rinnalla kehittyi tietokonevälitteinen viestintä (computer-mediated communication, CMC), jolla ei kuiten- kaan suoraan viitata opetusnäkökulmaan vaan yleisemmin tietokonevälitteisyyteen, erityisesti viestintään. Usein käytetään pitempää CMHClyhennettä (computer-mediated human communication) viittaamaan erityisesti ihmisten väliseen mutta tietotekniikkaperustaiseen viestintään, erotuksena esimerkiksi yritysten välisestä dataliikenteestä.

Terminologisena havaintona voidaan tähdentää sitä, että ICT on onnistuneesti suomentunut tieto- ja viestintätekniikaksi (TVT), ei -teknologiaksi, koska suomen kielessä tekniikka viittaa sekä taitoon että tekniseen alueeseen.

Englannin kielessä ICT on lähes vakiintunein nykykäsite kuvattaessa tieto- ja viestintätekniikka. Jotkut tutkijat suosivat uutta TVT:aa (new ICT, NICT), jotkut uudempaa tekniikkaa (newer technologies). Uusi sanan käyttöä voidaan ehkä kritikoida siitä, että valtaosa TVT:n sovelluksista käyttää periaatteessa hyvinkin vanhaa tekniikkaa, nimittäin puhelintekniikkaa. Uusi-termin käyttöä voisi toisaalta kyllä puoltaa mm. sillä perusteella, että viiteryhmän muodostavat kulloisenkin käyttäjäryhmän kannalta heille uudet tekniset sovellukset.

Yhtenä uudismuodosteena on otettu käyttöön MICT (modern information and communication technologies, moderni tieto- ja viestintätekniikka), jonka etuna on $\mathrm{mm}$. se, että päähuomio voidaan näin kiinnittää uusimpiin teknisiin innovaatioihin ja niiden opetussovelluksiin. Samalla implisiittisesti otetaan kantaa modernismin kehitysvaiheisiin, joskin tästä perspektiivistä tarkasteltuna olisi varmaan pian tarve siirtyä post-moderniin TVT:hen!

Jos puolestaan seuraa esimerkiksi Australiassa viime vuosina melko kiihkeänäkin käynyttä keskustelua teollisuustuotannon metaforan ("fordismin") rinnasteisuudesta kasvatusalaan, voisi ehkä perustellusti puhua myös "postfordistisesta" tieto- ja viestintätekniikasta, jolloin esimerkiksi korostuisi työntekijän, oppijan, viestijän, yleensäkin ihmisen oma vastuu työ- tai opiskelusuorituksestaan. Pessimistisemmät äänenpainot puolestaan ovat ristineet toistaiseksi 


\section{ARTKKKET}

uusimmatkin tekniikan koulusovellukset "postladaistisen" ajan tuotteiksi eli siis laatutasoltaan vielä riittämättömiksi mutta kuitenkin toivoa herättäviksi (esimerkiksi Lowe 1997).

\section{Kohti verkostopohjaista oppimista}

Tekniikan viime vuosien nopea kehitys erityisesti Internetin ja World Wide Webin alueella on kuitenkin johtanut tilanteeseen, jossa voidaan puhua jo pedagogisen paradigman muutoksesta. Ei liene enää perusteetonta väittää, että olemme siirtyneet CBE-tyyppisestä paradigmasta NBL-paradigmaan, jossa uutena peruskäsitteenä voidaan pitää verkostopohjaista oppimista. Tekninen kehitys on siis nyt mahdollistanut ilmiön, josta vielä 15 vuotta sitten haveilivat lähinnä Ted Nelsonin kaltaiset hypertekstivisionäärit. Tässä artikkelissa kehitystä on tarkasteltu erityisesti tieto- ja viestintätekniikoiden yhdistymisen ja tietokoneavusteisen opetuksen näkökulmasta. Yhtä perusteltua voisi olla verkostopohjaisen oppimisen johtaminen pitkästä etä- ja monimuoto-opetustraditiosta.

Mikä verkostopohjaista opiskelua tällä hetkellä luonnehtii? Olennaisia tällä hetkellä ovat verkkopohjaiset groupware- eli ryhmätyöohjelmistot, jotka mahdollistavat erilaisten käyttäjien ja käyttäjäryhmien välisen yhteistyön verkossa. Tämä kollaboratiivinen tiimityö lisääntynee voimakkaasti erityisesti aikuisopiskelussa ja työelämässä, mutta sitä sovellettaneen yhä enemmän myös perus- ja toisen asteen koulutukseen. Globaalin tavoitettavuuden (accessibility) ansiosta verkkoon hajautettuja resursseja voidaan käyttää paikallisesti. Vanha motto voidaan siis ilmaista muodossa: Think globally, act locally. Verkostopohjainen opiskelu on helppo mieltää myös osaksi elinikäisen oppimisen työvälineistöä ja opiskeluympäristöä.

Mielenkiintoisia sosiologisia ilmentymiä tästä teknisestä kehityksestä ovat mm. fragmentaatio ja integraatio. Fragmentaatio liittyy yhteisön, esimerkiksi koulun, perinteisesti varsin yhtenäisen toimintakokonaisuuden pirstoutumiseen, fragmentoitumiseen, koska osa sen ole- massaoloa selittyy tai välittyy verkon kautta. Voisi jopa väittää, että postmodernissa tieto- ja viestintäyhteiskunnassa koulun - tai minkä hyvänsä oppivan organisaation - oman olemassaolon oikeutus, raison d'être, perustuu fragmentaation ja integraation keskinäiseen tasapainoon. Integraatio viittaa pedagogiseen ja organisatoriseen integraatioon, joiden ansiosta pienikin koulu saa osakseen verkossa jaetut resurssit sekä oman sisäisen päätöksentekonsa lisäksi ulkoista, jaettua päätöksentekovaltaa. Integraation etuina on myös se, että koulu saa käyttöönsä intressi- ja tarveperustaisen harkintavallan, johon se ei ilman verkottumisyhteistyötä pystyisi. (Vrt. esim. Tella \& Kynäslahti 1997)

Verkostopohjaista oppimista luonnehtivat edelleen hajautettu asiantuntijuus, jossa ihmisen työsuoritusta on jaettu ihmisen ja koneen kesken. Nykymaailman ongelmista monet ovat sellaisia, joita ihminen ei välttämättä pysty suorittamaan yksin eikä koneensa kanssa. Tällaisissa tilanteissa verkkojen kautta avuksi saatava asiantuntijuus on arvokas lisä. Jo pitkään on havaittu, että verkoissa olevat asiantuntijat voivat olla poikkeuksellisen altruistisia, epäitsekkäitä jakaessaan tietämystään muiden verkossa olevien kesken. Eräiden arvioiden mukaan verkostoepäitsekkyys voi kuitenkin vähetä, jos kasvatuksen esineellistyminen ("commodification education") valtaa alaa. Tällöin kuluttajametafora (consumer metaphor) muuttaa verkossa liikkuvan information samoin kuin koulutustarjonnankin kauppatavaraksi, jolle markkinat eli kysynnän ja tarjonnan lait määräävät hinnan. Jossain määrin näin on jo tapahtunutkin ja yleisesti puhutaan esimerkiksi koulutuspaketeista.

Yksi tällä hetkellä verkoissa havaittava ilmiö on kuitenkin yksilöllisyyden kasvu, sillä emme ole tekemisissä pelkkien työvälineiden kanssa. Esimerkiksi Jonassen (1995; ks. myös Tella 1997, 40-46) puhuu neljästä erilaisesta ympäristöstä tekniikan kannalta. Näistä ensimmäinen funktio on välineellinen, instrumentaalinen. Toinen funktio liittyy uudenlaiseen kontekstiin, kolmas älylliseen partneriuteen - ylimalkaan ottaen 'new partnerships' ovat osa verkostokult- 
tuuria - ja neljäs uudenlaiseen oppimis-, työ- ja viestintäympäristöön, joka syntyy uusien tietoja viestintäteknisten välineiden, ohjelmien ja laitteiden ollessa harmoniassa ihmisen oman työkuvan tai tavoitteellisen opiskelun kanssa.

On oletettavissa, että NBL aikaansaa ennalta näkemättömän määrän sovelluksia. Yhtenä varhaisena sovelluksena voinee pitää nyt käytettävissä olevia laitteita, joissa televiestintätoiminnot on integroitu yhteen tuotteeseen ja joissa painottuvat viestintäominaisuudet ja suhteellisen vaivaton yhteys viestintäverkkoihin. On kuitenkin selvää, että kyseessä on vain välivaihe ennen olennaisesti viestintäpainotteisempia opetussovelluksia. Yhtenä ennakko-oireena voinee pitää loppukesästä 1997 ennakoitua matkapuhelinten smart messaging -kehitysvaihetta, jossa yhteys Internetiin toteutetaan älykkäillä agenttiohjelmilla. Samoin verkostoyhteydet television tai jopa tavallisen sähköverkon kautta ovat lähellä.

\section{Verkostojen kehityksestä}

Verkostopohjaisuudesta puhuttaessa on tietysti tarpeen kysyä, mistä verkostosta on kyse. Yleisesti lehdissä ja ihmisten suussa mainittu Internet on tällä hetkellä oikeastaan enää Internet1, jonka loppua tai romahdusta odotetaan ammattipiireissä enemmän tai vähemmän kiihkottomasti. Vakavampi mielenkiinto kohdistuu tällä hetkellä jo Internet2:een.

Internet 2 on osa presidentti Clintonin lokakuussa 1996 julkistamaa Next Generation Initiative -hanketta. Internet2 käyttää korkeanopeuksista datansiirtoverkkoa, jossa nopeudet ovat vähintään 100-kertaiset Internet1:een verrattuna. Internet2:een kuuluu tällä hetkellä Yhdysvaltain National Scientific Foundation, 112 yliopistoa ja teknologiayrityksiä. Verkkoon liitettäneen muutama Euroopan ja Aasiankin yliopisto, mutta tärkeimpänä tavoitteena pidetään kuitenkin Yhdysvaltain omaa kilpailuasetelmaa. Verkon kehittämisen päälähtökohtina ovat kuitenkin myös tavallista kansalaista hyödyttävät palvelut, esimerkiksi lähes tosiaikainen liikku- van kuvan sekä CD-tasoisen äänen välitys (ks. esim. http://www.internet2.edu). Vaikka toisaalta voidaankin väittää, että verkot ja niihin pohjautuvat palvelut nopeutuvat joka tapauksessa, Internet2:n kaltainen aloite on hyvä esimerkki teknologisten haittojen vähentämisestä kehitystä tietoisesti nopeuttamalla.

Eurooppalaisittain ajatellen tiedon valtaväylien kehittäminen ei ole vanhan väylän "romahtamisen" tai tukkiutumisen odottelua ja sen korvaamista kertaiskulla jollain uudella verkolla. Kehitys nähdään pikemminkin asteittaisena nykyisten väylien leventämisenä ja uusien palvelujen rakentamisena. Nopeuden lisääminen on toki tärkeä tavoite, mutta se toteutuu samalla kun muuta teknistä ja sisällöllistä infrastruktuuria kehitetään.

\section{Verkostot artifaktien maailmassa}

Tässä artikkelissa kuvattu ja kuviossa 1 tiivistetty kehityskulku voi toimia perustana, kun lähdemme pohtimaan sitä, miten nykyinen verkostopohjaisuus tulee käsitteellisesti hallita. Teknisen kehityksen myötä käyttäjän "työkalupakkiin“ on tullut sellainen määrä välineitä ja ohjelmistoja, että on aika konseptuaalistaa niiden funktioita johonkin yleisempään viitekehykseen.

Yhden käsitteellistämismallin tarjoaa Wartofskyn (1979) artifaktien kolmiportainen luokitus. Esitän seuraavassa hänen luokittelunsa Colen (1995) laajentamana, ja lisään siihen omia tulkintojani. Colen $(1995,194)$ argumentaatio lähtee siitä, että kulttuuri edustuu klassisissa kulttuurihistoriallisen psykologian lausunnoissa vain rajallisesti ja abstrahoidusti tavalla, jolla pyritään korostamaan välitteisyyden (mediation) olemusta artifaktien kautta. Artifaktit ovat toisiinsa kietoutuneita, ihmisten sosiaalista elämää välittäviä ilmiöitä, jotka muodostavat kokonaisuudessaan inhimillisen elämän ainutlaatuisen välineen (medium), jonka käsitteellistämme kulttuuriksi.

Wartofskyn (1979) luokittelussa primaareibin 
artifakteibin (primary artifacts) kuuluvat klassiset työvälineet kuten kirveet, neulat, kulhot. Cole (1995, 195-196) liittää tähän tasoon myös tietokoneet, viestintäverkot (telecommunications networks) ja myyttiset kulttuurihahmot. Tämä kategoria vastaa pitkälti tavallisen kielenkäytön työvälinekäyttöä.

Toisen tason artifakteissa (secondary artifacts) edustuvat puolestaan primaarit artifaktit ja ne toimintamoodit, joissa käytetään primaareja artifakteja. D’Andrade (1984, 93) sisällyttää tähän tärkeänä luokkana kulttuuriset mallit (cultural models), jotka kuvaavat ei vain fyysisten esineiden maailmaa vaan myös abstraktimpia maailmoja kuten sosiaalista interaktiota, diskurssia ja sanojen merkityksiä. Colen $(1995,195)$ tulkinnan mukaan toisen tason artifaktit ovat olennaisen tärkeitä säilyttämään ja välittämään toiminnan eri tapoja (modes of action).

Kolmannen tason artifaktit (tertiary artifacts) edustavat suhteellisen autonomisia maailmoja, joiden säännöt, totunnaisuudet ja tulokset eivät enää näytä suoraan käytännöllisiltä tai jotka todella vaikuttavat muodostavan ei-käytännöllisen toiminta-areenan tai edustuvan 'vapaassa' tai pelinomaisessa toiminnassa (Wartofsky 1979, 208). Colen $(1995,195)$ tulkinta kolmannen tason artifakteista käsittää mahdolliset kuvitellut maailmat, joita ihminen luo toimintansa monipuolistamiseksi. Hänen mukaansa tällaiset kuvitellut maailmat laajentavat ja rikkovat perinteisen 'praktisen' maailman rajoja ja reunaehtoja ja muodostavat välineen tavanomaisen käytännön muuttamiseksi. Lisäksi kun ollaan tekemisissä kolmannen tason artifaktien kanssa, käyttäytymismallit voivat edetä niiden käytön välittömien kontekstien ulkopuolelle, "uusien mahdollisuuksien maailmoihin". Wartofsky viittaa tässä yhteydessä erityisesti taiteen maailmaan sekä havaintoprosesseihin. Cole $(1995,195)$ puolestaan laajentaa tätä artifaktien tasoa käsittämään myös sellaiset toiminnot, joiden tavoitteena on edistää lasten sosiaalista ja kognitiivista kehittymistä. On tärkeää huomata, että tekninen kehitys on nyt mahdollistanut tämän tason artifaktit ennenkokemattomal- la tavalla. Samalla siirtymä tietokoneperustaisesta opetuksesta verkostopohjaiseen oppimiseen mahdollistuu huomattavasti.

Esitetty luokittelu herättää luonnollisesti jatkopohdintoja. Ensinnäkin voisi yhtyä Colen tulkintaan siitä, että viestintäverkot ovat primaareja artifakteja siinä vaiheessa kun niiden käyttö tietoyhteiskunnassa on suunnilleen yhtä itsestäänselvää tai perustavanlaatuista kuin kirveen tai puukon agraariyhteiskunnassa. Kehityksen nykyvaiheessa verkko tai verkosto viittaa ylempänä esitettyyn Internet1-verkkoon eli Internetiin lähinnä sellaisena kuin me sen nyt tunnemme. Visionääristä tässä Colen rinnastuksessa on mielestäni se, että kun useimpien ihmisten mielessä viestintä- tai tietokoneverkko on jokin abstraktio, jopa ylin taso teknisessä kehityksessä, Cole näkee verkot sen sijaan jo hyvin konkreettisina ja pragmaattisina työvälineinä, joita itse kutsuisin tässä yhteydessä 'esineellistyneiksi abstraktioiksi'. Kehitystä voisi ehkä luonnehtia siirtyminä fyysisen verkon ongelmista sosiaalisen verkon korostamiseen ja sen myötä erilaisen viestinnän ja ihmistenvälisen kanssakäymisen muotojen ja sisältöjen tarkasteluun.

Kolmannen tason artifaktit herättävät myös pohdintaa. Olisiko niin, että yllä karkeistaen hahmoteltu Internet2 edustaisi tässä vaiheessa tätä uusien mahdollisuuksien tasoa, muuttuakseen ehkä viiden vuoden kuluttua primaariartifaktiksi? Toisaalta jos haluamme ymmärtää Wartofskyn kolmannen tason mahdollisina kuviteltuina maailmoina, silloin olemme jo lähellä virtuaaliluokan tai virtuaalikoulun sekä virtuaalisuuden käsitteitä (esim. Tella 1995; Kynäslahti 1997). Kynäslahti (1997, 49) on ansiokkaasti analysoinut virtuaalisuuden ja mahdollisten maailmojen välisiä suhteita $\mathrm{mm}$. siteeraamalla Kusch \& Hintikkaa $(1988,39)$ ja Quéauta (1995, 16) siitä, että virtuaalisuus ("lume") vie ihmisen toiseen todellisuuteen, joka voi olla järkevä tai järjetön, johdonmukainen tai ristiriitainen, fyysinen tai fantastinen.

Kuviteltuja fantasiaan perustuvia klassikkoja ovat MUD- ja MUSE-tietokonemaailmat. MUD 
(multi-user dungeon) ja MUSE (multi-user simulation environment) ovat maagisia, tähän asti tavallisesti tekstiperustaisia maailmoja, joissa kulkijat voivat omaksua joustavia, anonymisiä henkilöhahmoja ja kokea jännittäviä dramaattiseen muotoon jäsentyviä tilanteita (Dede 1995, 48). Kuten olen todennut eri teknisiä välineitä ja niiden hallintatasoja koskevassa luokittelussani (Tella 1997, 18-23), MUD- ja MUSE-tyyppisten fantasiamaailmojen tärkein tavoite on yhdistää oppiminen ja kokemusperäisyys tietokoneperustaisissa kuvitelluissa, "kolmannen tason artifakteja" edustavissa virtuaalimaailmoissa. Ihminen on toki voinut pelata esimerkiksi roolipelejä ilman tietokonetta ja ilman verkkojakin, mutta tieto- ja viestintätekniikan kehittyminen on antanut näille inhimillisen toiminnan alueille uusia ulottuvuuksia.

Olemme näin edenneet suhteellisen kauas konkreetista luokkahuoneympäristöstä, jossa viestintäverkkoja käytetään. Olisi luontevaa jatkaa edelleen vaikka Mäkelän (1996, 34-35) ja Kynäslahden $(1997,51)$ viitoittamalla polulla, jossa verkostotyöskentely korvaa perinteisiä yhteisöulottuvuuksia, kuten ryhmän, yhteiskunnan ja antaa samalla verkoissa liikkuvalle uusia identiteettejä. Kolmannen tason artifaktien mahdollisissa maailmoissa habitat, ihmisen kotipaikka, on siinä vuorovaikutuksessa, jonka käyttäjät luovat itselleen ja muille käyttäjille. Perimmältään kyse on uudentyyppisestä kulttuuri-ilmiöstä, joka on syntymässä verkostopohjaisuuden varaan.

Kasvatuksen ja opetuksen kannalta haastavaa on siis tarkastella toisen ja kolmannen tason artifakteja. Olennaista niissä on nimenomaan toimintatapojen yhdistäminen primaaritason artifakteihin sekä vuorovaikutuksen, dialogismin ja välitetyn toiminnan (mediated action) syvällinen ymmärtäminen. Tästä suunnasta tulkittuna tässä artikkelissa hahmoteltu paradigmaattinen siirtymä tietokoneperustaisesta opetuksesta verkostopohjaiseen oppimiseen voi hyvinkin toimia uuden toimintakulttuurin ponnahduslautana. Seuraavassa vaiheessa tärkeää on pohtia, millä tavoin ja keinoin toimintatapoja - sekä opetuskäytänteitä että opiskelustra- tegioita - tulisi verkostopohjaisessa oppimisessa kehittää. Tämän pohdiskelun kannustimena olkoon vanha totuus siitä, että inhimillisen kehityksen paras konteksti on aina kulttuuri, ei koskaan yksittäinen tekniikka tai teknologia.

\section{Iätret}

COLE, M. (1995). Socio-cultural-historical psychology: some general remarks and a proposal for a new kind of cultural-genetic methodology. In Wertsch, J. V., Del Rio, P. \& Alvarez, A. (eds.) 1995. Sociocultural Studies of Mind. Cambridge: Cambridge University Press, 187214.

D'ANDRADE, R. (1984) Cultural meaning systems. In Shweder, R. A. \& Levine, R. A. (eds.) Culture theory: Essays on mind, self, and emotion. Cambridge University Press, 88-122.

DEDE, C. (1995) The Evolution of Constructivist Learning Environments: Immersion in Distributed, Virtual Worlds. Educational Technology September-October, 46-52.

JONASSEN, D. H. (1995) Supporting Communities of Learners with Technology: A Vision for Integrating Techno$\log y$ with Learning in Schools. Educational Technology July-August, 60-63.

KIVINEN, A. \& KONTTINEN, R. (1985) Tekstinkäsittelyobjelmien ominaisundet ja opetuskäyttö. Kasvatustieteiden tutkimuslaitos. Jyväskylän yliopisto.

KUSCH, M. \& HINTIKKA, J. (1988) Kieli ja maailma. Oulu: Pohjoinen.

KYNÄSLAHTI, H. (1997) Virtuaaliluokkaa etsimässä. Teoksessa Salminen, J. (toim.) Etäopetus koulussa: Kilpisjärvi-projekti 1994-1997. Helsingin yliopisto. Helsingin II normaalikoulun julkaisuja 1, 48-61.

LOWE, I. (1997) Open and distance learning: Education for the future. In Osborne, J., Roberts, D. \& Walker, J. (eds.) Open, Flexible and Distance Learning: Education and Training in the 21st Century. Proceedings of the 13th Biennial Forum of the Open and Distance learning Association of Australia (in association with the Australian Association of Distance Education Schools). University of Tasmania, Launce ston. 29 September - 3 October 1997, 256-262.

MÄKELÄ, A. (1996) Mediatutkimus ja mediakulttuuri. Teoksessa Tarkka, M., Hintikka, K. \& Mäkelä, A. (toim.) Johdatus unteen mediaan. Helsinki: Edita, 1939

QUÉAU, P. (1995) Lumetodellisuns. Art House.

TELLA, S. (1991) Introducing International Communications Networks and Electronic Mail into Foreign Language Classrooms: A Case Study in Finnish Senior Secondary Schools. Department of Teacher Education. University of Helsinki. Research Report 95.

(Summary: http://www.helsinki.fi/ tella/95abst.html)

TELLA, S. 1992a. Boys, Girls, and E-Mail: A Case Study in Finnish Senior Secondary Schools. Department of Teacher Education. University of Helsinki. Research 


\section{ARTKKKET}

Report 110

(Summary: http://www.helsinki.fi/ tella/110abst.html)

TELLA, S. (1992b) Talking Shop via E-mail: A Thematic and Linguistic Analysis of Electronic Mail Communication. Department of Teacher Education. University of Helsinki. Research Report 99.

(Summary: http://www.helsinki.fi/ tella/99abst.html)

TELLA, S. (1995) Virtual School in a Networking Learning Environment. Department of Teacher Education. University of Helsinki. OLE Publications 1. (http:// www.helsinki.fi/ tella/ole1.html

TELLA, S. (1997) An 'Uneasy Alliance' of Media Education and Multiculturalism, with a View to Foreign Language Learning Methodology. University of Helsinki. Department of Teacher Education. OLE Publications 4.
(Summary: http://www.helsinki.fi/ tella/ole4sum.html) TELLA, S. \& KYNÄSLAHTI, H. 1997. A School Facing a Network of Other Schools. In Osborne, J., Roberts, D. \& Walker, J. (eds.) Open, Flexible and Distance Learning: Education and Training in the 21st Century. Proceedings of the 13th Biennial Forum of the Open and Distance learning Association of Australia (in association with the Australian Association of Distance Education Schools). University of Tasmania, Launceston. 29 September - 3 October 1997, 450-454.

(http://www.helsinki.fi/ tella/odlaasthk.html)

WARTOFSKY, M. 1979. Models. Dordrecht: Reidel.

Artikkeli on saa punut 15.9.1997. Se hyvä ksyttiin julka ista va ksito imituskunnan kokouksessa 10.11. 